\title{
Is colour an important factor influencing the behaviour of butterflies (Lepidoptera: Hesperioidea, Papilionoidea)?
}

\author{
LENKa KOČÍKOVÁ ${ }^{1}$, DANa MIKLISOVÁ2, AleXANDER ČANÁDY ${ }^{1}$ and Lubomír PANIGAJ ${ }^{1}$ \\ ${ }^{1}$ Institute of Biology and Ecology, Faculty of Science, P.J. Šafárik University, SK-04001, Košice, Slovakia, \\ e-mail: lenka.kocikova@student.upjs.sk \\ ${ }^{2}$ Institute of Parasitology, Slovak Academy of Sciences, Hlinkova 3, SK-04001, Košice, Slovakia
}

Key words. Lepidoptera, colour preference, water pan traps, Western Carpathians

\begin{abstract}
Coloured Moericke water pan traps were used to determine the effect of colour on the preference behaviour of butterflies (Lepidoptera: Hesperioidea, Papilionoidea) over the period 2001 to 2003 in grassland habitats in Eastern Slovakia (Košická kotlina basin). A total of 912 individuals belonging to 53 species and 7 families of butterflies were trapped. The colour of the traps that caught the most butterflies was white, followed by blue, violet, yellow and finally the least were caught by red coloured traps. Ordination analysis showed that some butterfly families and species were more likely to be caught by traps of a specific colour. Measurements of the wavelengths of the colours used revealed that butterflies preferred short-wavelengths light. The effect of colour on the catches did not differ significantly among the sites. The butterflies were more likely to be caught by traps of a certain colour even though the other features of the traps were the same.
\end{abstract}

\section{INTRODUCTION}

Many insects utilise the pollen and nectar of flowers. Flowers are an unreliable and scattered food source in certain habitats and therefore, insects need to have sensory systems and a learning capacity suitable for them to forage efficiently. This ability allows them to distinguish well-known from unfamiliar flowers or profitable from an unprofitable food sources (Chittka \& Menzel, 1992). Plants require more than the occasional visit from pollinators, therefore they have evolved sets of characters that are understandable to insects, which are meant to be attracted. Thus, plants and pollinators are able to communicate with each other (Prajakta et al., 2009). Herbivorous insects searching for a food source base their choices on a variety of criteria, including $\mathrm{CO}_{2}$ concentration (Stange, 1997) and colour (Kinoshita et al., 1999; Spaethe et al., 2001; Chittka \& Raine, 2006). In addition to olfactory discrimination visual recognition seems to be equally important and according to Chittka \& Menzel (1992) colour vision may be the most important means of locating flowers from a distance, because odour is unlikely to reach as far and given the relatively poor three-dimensional resolution of an insect eye, floral shape or a pattern also cannot be distinguished from afar. Plants thus might use colours as long distance signals for attracting mutualists and repelling antagonists. Therefore, we decided to determine whether colour is one of the main factors influencing the behaviour of adult butterflies searching for a food source.

An essential prerequisite for this ability is a colour vision that enables them to differentiate between flowers of different species (Chittka \& Menzel, 1992). Insect eyes contain specific sets of photosensitive cells that determine their colour vision abilities.
All the insects that have been examined have at least two different types of receptor, one sensitive to the ultraviolet part of the spectrum (maximum sensitivity close to $350 \mathrm{~nm}$ ) and the other sensitive to green (maximum sensitivity at ca. $540 \mathrm{~nm}$ ). This enables them to compare the long and short-wavelength parts of the spectrum. Most insects have an additional receptor that is sensitive to blue with maximum sensitivity at ca. $440 \mathrm{~nm}$ (Kelber, 2001). The existence of more than three different types of receptor cells with different spectral sensitivities in a compound eye is indicated by the pentachromatic colour vision system in the Japanese Yellow Swallowtail butterfly, Papilio xuthus (Lepidoptera, Papilionidae), which was first described by Arikawa et al. (1987).

The perception of colour varies among various insects orders. For instance, uv-blue (around $410 \mathrm{~nm}$ ) is preferred by naive honeybee foragers (Hymenoptera: Apidae), whereas naive bumblebees (Hymenoptera: Apidae) have a particular preference for wavelengths between 400 and $420 \mathrm{~nm}$ (Giurfa et al., 1995; Gumbert, 2000). On the other hand, red is an attractive colour for females of common thrips (Thysanoptera: Thripidae) (Yaku et al., 2007). Host seeking tabanid flies (Diptera: Tabanidae) are also attracted to red, but also to blue and black (Sasaki, 2001). Researchers studying Diptera are aware that yellow (Moericke, 1951) or yellow and white (Straka et al., 2010) are the most attractive for many dipteran groups. Hence, even traps designed to imitate flowers are usually yellow (Grissel \& Schauff, 1997b; Roháček et al., 1998; Beneš et al., 2000; Kocourek et al., 2002). Only a few studies have used trap colours other than yellow. Bäschli \& Blasco-Zumeta (1995) and zur Strassen et al. (1997) used different coloured traps in their 
studies on Thysanoptera and Diptera, but do not mention flower colour preference.

The visual appearance of flowers especially their colour, seems to be critical for an important nectarfeeding group, the butterflies (Ilse, 1928; Goulson \& Cory, 1993; Weiss, 1995a). Ilse (1928) demonstrated that butterflies have an inborn preference for a certain colour and moreover preferences differ among butterfly families. An exquisite example of colour selection is that of butterfly preference for the flowers of the woody shrub Lantana camara L. (Verbenaceae), the flowers of which undergo a dramatic change in colour and reward level. Newly opened L. camara flowers are yellow and provide a nectar reward and are thereby attractive to butterflies that pollinate them; older flowers, while still fresh and in bloom, turn red and do not contain any nectar (Weiss, 1995b). In another study of colour choices made by butterflies, Papilio aegeus females prefer to oviposit on substrates that look green to humans. The green receptor has a positive influence on ovipositing females, therefore, females lay their eggs on young leaves, which are indeed the best food for a young caterpillar (Kelber, 1999).

There are many studies that support the theory that flower colour has some influence on the behaviour of many species of insects. The few records on the flower colour preferences of butterflies in Central Europe induced us to carry out a field test using various coloured water pan traps. Using this method we captured relatively large numbers of butterflies and used ordination analyses of the catches to investigate the preferences for particular colours of butterflies at the family and species levels.

\section{MATERIAL AND METHODS}

The study site is located in the Košice basin (Eastern Slovakia, Western Carpathians), near the village of Beniakovce, $4 \mathrm{~km}$ northwest of Košice $\left(48^{\circ} 46^{\prime} \mathrm{N}, 21^{\circ} 18^{\prime} \mathrm{E}\right.$; altitude: $\left.300 \mathrm{~m}\right)$ and on a northeast-oriented gentle slope on an abandoned pasture adjoining a forest. The herbaceous vegetation is partly ruderalised. The main nectar sources are Agrimonia eupatoria, Achillea millefolium, Cirsium arvense, Dianthus deltoides, Epilobium angustifolium, Fragaria vesca, Galium verum, Glechoma hederacea, Hieracium umbellatum, Hypericum perforatum, Lathyrus pratensis, Lotus corniculatus, Lychnis floscuculi, Medicago sativa, Polygala vulgaris, Potentilla argentea, Prunus spinosa, Ranunculus acer, Rosa canina, Rubus fruticosus, Solidago gigantea, Stellaria nemorum, Taraxacum officinale, Thymus pulegioides, Tithymalus cyparissias, Trifolium pratense, Trifolium repens, Veronica spicata and Viola tricolor.

In an area of approximately 20 ha, 10 groups of Moericke water pan traps (Moericke, 1951) for capturing insects were installed. The traps were made of plastic pans (upper diameter: $12 \mathrm{~cm}$, depth $6 \mathrm{~cm}$ ) for vegetable butter, painted in one of $5 \mathrm{col}-$ ours (DUPLI-COLOR - colour spray): white, yellow, blue, violet or red inside and green outside. Water with detergent (1 $\mathrm{mL}$ per $1 \mathrm{~L}$ of water) was poured into the traps until the depth of water was about $2 \mathrm{~cm}$ (Beneš et al., 2000). Odourless detergent was used to reduce the surface tension of the water. The traps were placed on a $30 \mathrm{~cm}$ long wire holder, at the same level as the surrounding vegetation.

The traps were exposed for ten days each month from May to September, and this was repeated for three years (2001-2003). They were distributed with the aim of having traps in all the habitats at the study site: xero-mesophilous grassland, edge of an oak-hornbeam forest and extensive shrubwood. In each habitat, five traps of different colours were placed in an area of $2 \mathrm{~m}^{2}$ in the form of a square, with the fith trap at the intersection of the squares diagonals. The groups of traps were placed at the same place throughout the research, but the distribution of traps within the groups was varied.

The trapped material was checked and collected at 2 day intervals, and the water with detergent in the traps top-upped. During the checks, the contents of traps were sieved, individual Lepidoptera separated and recorded according to species and colour of the trap.

The UV-Vis spectra of the colours used were measured using a SPECORD ${ }^{\circledR}$ S 300 UV VIS spectrophotometer in acetone in a quartz cuvette $\left(1 \mathrm{~cm}\right.$ path length) at $25^{\circ} \mathrm{C}$. The peaks (representing the monochromatic elements of the colours) for each colour were identified.

The effect of the different time of trapping (month and year) and different coloured traps on number of Lepidoptera caught were tested using the Main-effect ANOVA and post hoc Fisher LSD multiple range test in STATISTICA 9.0 (StatSoft, Inc., 2009). A similar analysis was done with species as the extra factor. The data that did not meet the requirements for parametric statistical tests, were $\log$ transformed $[\ln (\mathrm{x}+1)]$ in order to fit ANOVA assumptions (normal distribution and homogeneity of variances).

The possible effect on the colour preferences of the butterflies of the incidence of different coloured flowers was also taken into account. Relations between attractiveness of traps of different colours for the butterflies and the incidence of flowers of different colours were analysed using Spearman's rank correlation coefficient.

To study the colour preference of individual butterfly families and species, untransformed family and species data were assessed using the PCA ordination method (as the length of the gradient using the DCA method was 1.57 and 0.92, respectively) in CANOCO (ter Braak \& Šmilauer, 2002). In this case the scaling focused on inter-species correlations and species scores were divided by standard deviation and centering by species. Sixteen infrequent species (only one individual captured in a particular coloured traps during the tracking period) were not included in the ordination analysis. Species arrow shows the direction of steepest increase in values for the corresponding species, the closer the heads of arrows, the more positively correlated are the species. Species that are closer to the colour indicator correlate positively, i.e. they have an obvious preference for a specific colour. The colour similarity according to Lepidoptera species trapped in coloured traps was evaluated using cluster analysis (Complete linkage method, Euclidean distance) using STATISTICA 9.0 (StatSoft, Inc., 2009).

\section{RESULTS}

Throughout the duration of the trapping period, 912 individuals belonging to 53 species and 6 families of butterflies (Lepidoptera: Hesperioidea, Papilionoidea) were captured (Table 1). Of the most abundant species, Melitaea athalia (with total dominance $22.59 \%$ - 206 indiv.) dominated the total catch, followed by Pieris rapae (12.39\% - 113 indiv.), Maniola jurtina (9.65\% - 88 indiv.), Coenonympha pamphilus (5.48\% - 50 indiv.), Coenonympha glycerion (5.26\% - 48 indiv.) and Thymelicus lineola $(5.26 \%-48$ indiv.). Occurrence of other species was below $5 \%$. 
TABLE 1. List of butterflies (Lepidoptera: Hesperioidea, Papilionoidea) caught by water pan traps of particular colours in East Slovakia from 2001 to 2003 (species names according to Laštůvka, 1998).

\begin{tabular}{|c|c|c|c|c|c|c|c|c|c|c|c|c|c|c|c|c|c|c|c|c|}
\hline \multirow{2}{*}{ S.n. } & \multirow{2}{*}{$\begin{array}{l}\text { Abbrev. } \\
\text { of spp. }\end{array}$} & \multirow{2}{*}{ Species } & \multicolumn{6}{|c|}{2001} & \multicolumn{6}{|c|}{2002} & \multicolumn{6}{|c|}{2003} \\
\hline & & & $\mathrm{W}$ & $\mathrm{B}$ & $\mathrm{V}$ & $\mathrm{Y}$ & $\mathrm{R}$ & Total & $\mathrm{W}$ & $\mathrm{B}$ & $\mathrm{V}$ & $\mathrm{Y}$ & $\mathrm{R}$ & Total & W & $\mathrm{B}$ & $\mathrm{V}$ & $\mathrm{Y}$ & $\mathrm{R}$ & Total \\
\hline 1 & Eta & Erynnis tages & - & - & - & - & - & - & - & 3 & - & - & - & 3 & - & - & - & - & - & - \\
\hline 2 & $\mathrm{Cal}$ & Carcharodus alceae & - & - & - & - & - & - & - & - & - & - & - & - & - & - & 1 & - & - & 1 \\
\hline 3 & Pma & Pyrgus malvae & - & - & - & - & - & - & - & 2 & 1 & - & - & 3 & 1 & 5 & 8 & 2 & - & 16 \\
\hline 4 & Cpa & Carterocephalus palaemon & - & - & - & - & - & - & - & - & - & - & - & - & - & - & 1 & - & - & 1 \\
\hline 5 & Hco & Hesperia comma & - & - & - & - & 1 & 1 & - & - & 1 & - & - & 1 & - & - & - & - & - & - \\
\hline 6 & Tsy & Thymelicus sylvestris & - & - & - & - & - & - & - & 2 & - & - & - & 2 & - & - & 1 & - & - & 1 \\
\hline 7 & Tli & Thymelicus lineola & 1 & 2 & - & - & 2 & 5 & 8 & 12 & 13 & 1 & - & 34 & 1 & 2 & 5 & 1 & - & 9 \\
\hline 8 & Ove & Ochlodes venatus & - & - & - & - & - & - & - & 7 & 5 & - & - & 12 & - & 8 & 3 & - & - & 11 \\
\hline 9 & Ipo & Iphiclides podalirius & - & - & - & 1 & - & 1 & - & - & - & - & - & - & - & 1 & - & - & - & 1 \\
\hline 10 & Lsi & Leptidea sinapis & 1 & - & - & - & - & 1 & - & 1 & - & - & - & 1 & 1 & 1 & - & - & - & 2 \\
\hline 11 & $\mathrm{Pbr}$ & Pieris brassicae & - & - & - & - & - & - & - & - & 1 & - & - & 1 & 3 & - & - & - & - & 3 \\
\hline 12 & Pra & Pieris rapae & 67 & 3 & 1 & - & 2 & 73 & 29 & - & 1 & - & - & 30 & 7 & 1 & 1 & 1 & - & 10 \\
\hline 13 & Pna & Pieris napi & 1 & - & - & - & - & 1 & 10 & - & 1 & - & - & 11 & 4 & - & 2 & - & - & 6 \\
\hline 14 & Pda & Pontia daplidice & - & - & - & - & - & - & - & - & - & - & - & - & - & - & 1 & - & - & 1 \\
\hline 15 & Chy & Colias hyale & - & - & - & - & - & - & - & - & - & - & 1 & 1 & - & - & - & - & - & - \\
\hline 16 & Ccr & Colias crocea & - & - & - & 1 & - & 1 & - & - & - & - & - & - & - & - & - & - & - & - \\
\hline 17 & Grh & Gonepteryx rhamni & 1 & - & - & - & - & 1 & - & - & 1 & - & - & 1 & - & - & - & - & - & - \\
\hline 18 & Hlu & Hamearis lucina & - & - & - & - & - & - & 1 & - & - & - & - & 1 & 3 & - & - & - & - & 3 \\
\hline 19 & Lph & Lycaena phlaeas & - & - & - & 1 & - & 1 & - & - & - & - & - & - & - & - & - & - & - & - \\
\hline 20 & Ldi & Lycaena dispar & - & - & - & - & - & - & 4 & - & - & - & 2 & 6 & 1 & - & 2 & - & - & 3 \\
\hline 21 & Lvi & Lycaena virgaureae & - & - & - & - & - & - & - & - & - & - & - & - & 1 & - & - & - & - & 1 \\
\hline 22 & Lti & Lycaena tityrus & - & - & - & - & 3 & 3 & - & - & - & - & - & - & 3 & - & 1 & - & - & 4 \\
\hline 23 & Tbe & Thecla betulae & - & - & - & 1 & - & 1 & - & - & - & - & - & - & - & - & - & - & - & - \\
\hline 24 & $\mathrm{Sac}$ & Satyrium acaciae & 1 & - & - & - & - & 1 & 3 & - & - & 3 & - & 6 & 2 & 1 & - & 5 & - & 8 \\
\hline 25 & Mar & Maculinea arion & - & - & - & - & - & - & - & - & - & - & - & - & - & - & - & - & 3 & 3 \\
\hline 26 & Par & Plebeius argus & - & - & - & - & - & - & - & - & - & - & - & - & - & - & - & - & 3 & 3 \\
\hline 27 & Cse & Cyaniris semiargus & - & - & - & - & - & - & - & - & 1 & - & - & 1 & - & - & - & - & - & - \\
\hline 28 & Pic & Polyommatus icarus & 3 & 1 & - & - & 1 & 5 & - & - & - & - & 1 & 1 & - & - & - & - & - & - \\
\hline 29 & Npo & Nymphalis polychloros & - & - & - & - & - & - & - & - & 1 & - & - & 1 & - & - & - & - & - & - \\
\hline 30 & Iio & Inachis io & 8 & 9 & 3 & 1 & - & 21 & - & - & - & 1 & - & 1 & 1 & - & - & - & - & 1 \\
\hline 31 & Vat & Vanessa atalanta & - & 2 & - & - & - & 2 & - & - & - & - & - & - & - & - & - & - & - & - \\
\hline 32 & Vca & Vanessa cardui & - & 1 & - & - & - & 1 & - & - & - & - & - & - & - & 1 & - & - & - & 1 \\
\hline 33 & $\mathrm{Pc}-$ & Polygonia c-album & - & 1 & - & - & - & 1 & - & - & - & - & - & - & - & - & - & - & - & - \\
\hline 34 & Ale & Araschnia levana & 5 & - & - & - & - & 5 & - & - & 1 & 1 & 1 & 3 & 8 & - & - & 2 & 3 & 13 \\
\hline 35 & Apa & Argynnis paphia & - & - & - & - & - & - & - & - & - & - & - & - & - & 2 & - & - & - & 2 \\
\hline 36 & Aad & Argynnis adippe & - & - & - & - & - & - & - & - & - & - & - & - & 1 & 1 & - & - & - & 2 \\
\hline 37 & Ila & Issoria lathonia & - & - & 1 & - & - & 1 & - & - & - & 2 & - & 2 & - & - & - & - & - & - \\
\hline 38 & Csl & Clossiana selene & 2 & - & - & - & - & 2 & 2 & - & - & - & - & 2 & 1 & - & 2 & - & 1 & 4 \\
\hline 39 & Bdi & Boloria dia & 1 & 5 & 8 & 2 & 5 & 21 & 4 & 5 & 5 & - & 15 & 29 & 2 & 5 & 6 & 3 & 10 & 26 \\
\hline 40 & Mat & Melitaea athalia & 12 & - & - & 5 & 6 & 23 & 45 & 22 & 30 & 9 & 28 & 134 & 13 & 9 & 11 & 5 & 11 & 49 \\
\hline 41 & Mci & Melitaea cinxia & - & - & - & - & - & - & - & - & 1 & - & - & 1 & - & - & - & - & - & - \\
\hline 42 & Mau & Melitaea aurelia & - & 2 & 1 & - & - & 3 & 4 & 6 & - & - & 3 & 13 & 12 & - & - & 4 & - & 16 \\
\hline 43 & Mga & Melanargia galathea & - & - & - & - & - & - & - & 4 & 2 & - & - & 6 & - & 2 & 1 & - & - & 3 \\
\hline 44 & $\mathrm{Mdr}$ & Minois dryas & - & 1 & - & - & - & 1 & - & - & - & - & 1 & 1 & - & 3 & 2 & 1 & 2 & 8 \\
\hline 45 & Eme & Erebia medusa & - & - & - & - & - & - & - & - & - & - & - & - & - & 1 & - & - & 1 & 2 \\
\hline 46 & $\mathrm{Mju}$ & Maniola jurtina & 2 & 3 & 1 & 3 & - & 9 & 11 & 10 & 7 & 5 & & 33 & 9 & 15 & 8 & 13 & 1 & 46 \\
\hline 47 & Ahy & Aphanthopus hyperanthus & - & 1 & - & 2 & - & 3 & - & 1 & - & 9 & - & 10 & 2 & - & 1 & 7 & - & 10 \\
\hline 48 & Cpa & Coenonympha pamphilus & 6 & 1 & 2 & 2 & 1 & 12 & - & - & - & 1 & 1 & 2 & 7 & 11 & 7 & 11 & - & 36 \\
\hline 49 & Car & Coenonympha arcania & - & - & - & - & - & - & - & - & - & - & - & - & 2 & - & - & - & - & 2 \\
\hline 50 & $\mathrm{Cgl}$ & Coenonympha glycerion & 5 & - & - & 6 & - & 11 & 1 & 2 & 3 & 3 & - & 9 & 7 & 4 & 9 & 8 & - & 28 \\
\hline 51 & $\mathrm{Pae}$ & Pararge aegeria & - & - & - & - & - & - & - & 1 & - & - & - & 1 & - & - & - & - & - & - \\
\hline 52 & Lme & Lasiommata megera & - & 1 & - & - & - & 1 & - & - & - & - & - & - & - & - & - & - & - & - \\
\hline 53 & Lma & Lasiommata maera & - & - & - & - & - & - & - & 1 & - & - & - & 1 & - & - & - & - & - & - \\
\hline Total & & & 116 & 33 & 17 & 25 & 21 & 212 & 122 & 79 & 75 & 35 & 53 & 364 & 92 & 73 & 73 & 63 & 35 & 336 \\
\hline Specie & s together & in each colour & 15 & 14 & 7 & 11 & 8 & & 12 & 15 & 17 & 10 & 8 & & 23 & 18 & 20 & 13 & 9 & \\
\hline
\end{tabular}




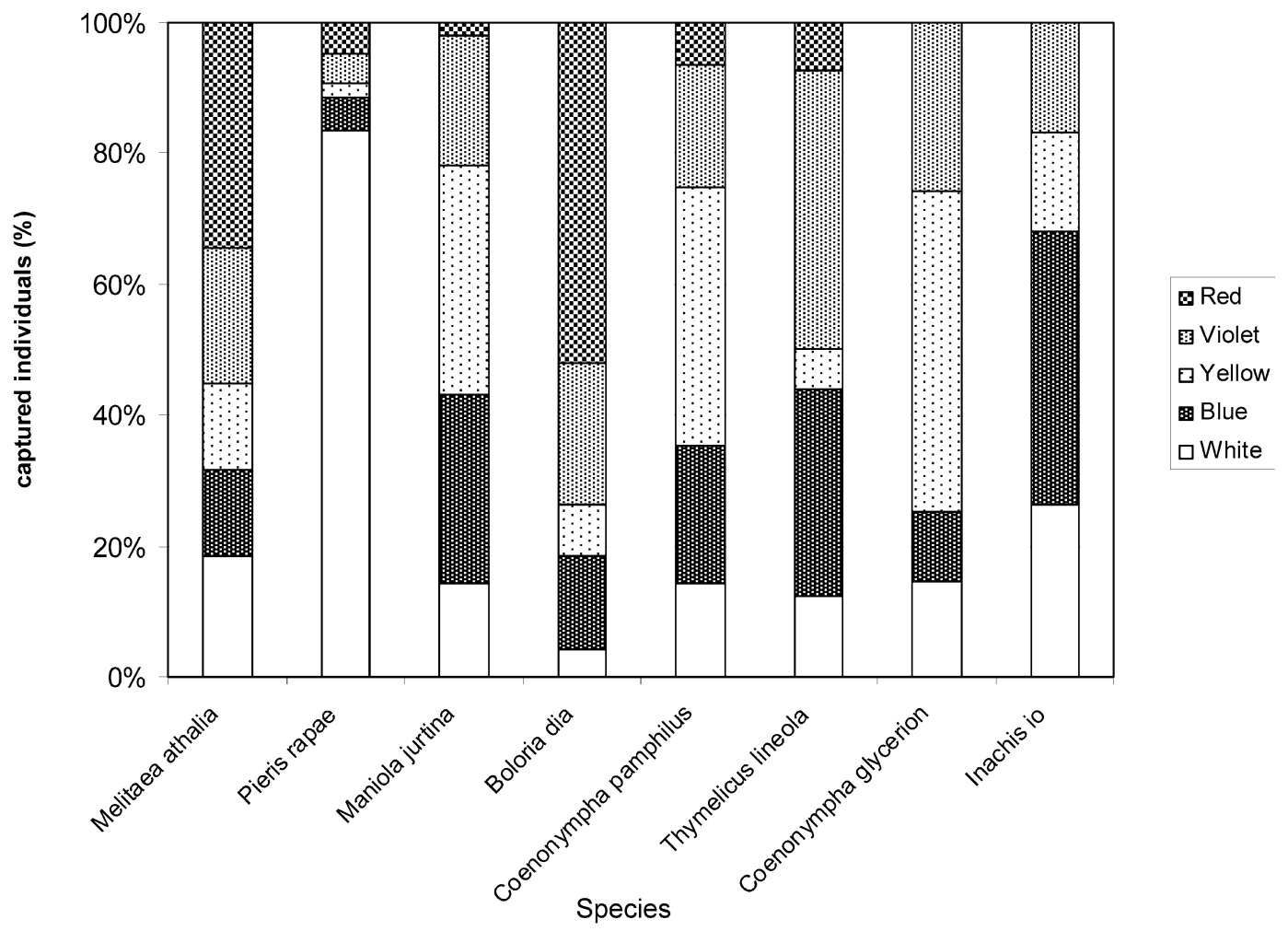

Fig. 1. Variability of colour flower preference by dominant species during the season 2001-2003.

The white coloured traps caught most butterflies (330 individuals) followed by blue (185), violet (165), yellow (123) and red (109). The effect of colour on the numbers of butterflies caught did not differ significantly among the sites. However, the traps of different colours did not catch similar but different numbers of individuals of each species of butterfly (Fig. 1). When we consider the preference for a particular colour at the species level, our results are as follows: 30 of the 53 species were caught by blue traps, 30 by violet traps, 24 by white traps, 19 by yellow traps and 18 by red traps.

Fig. 2 presents an overview of the number of species and individuals captured by traps of a particular colour.

Main-effect ANOVA showed that number of Lepidoptera trapped was significantly influenced by month $\left(F_{(4,66)}\right.$ $=6.67, P<0.001)$. The effects of year $\left(F_{(2,64)}=2.66, P=\right.$
$0.078)$ and colour $\left(F_{(4,64)}=2.37, P=0.066\right)$ were not statistically significant. The Main-effect ANOVA with species as the extra added factor gave slightly different results. It confirmed influence of colour $\left(F_{(4,782)}=6.8230\right.$, $P<0.0001)$, month $\left(F_{(4,782)}=4.8714, P<0.001\right)$ and species $\left(F_{(52,782)}=2.3926, P<0.00001\right)$, but not of the year $\left(F_{(2,782)}=2.5632, P=0.078\right)$. The Fisher post hoc test showed that the size of the catches of white coloured traps differed from those of the other traps $(P<0.05)$. The overview of number of Lepidoptera caught by the different coloured traps is given in the boxplot diagram (Fig. 3), which also reveals that the white coloured traps caught more butterflies than the other coloured traps.

Biplot ordination diagram based on PCA of the numbers of butterflies caught by different coloured traps is given in Fig. 4. The first axis explains about $82 \%$ of the

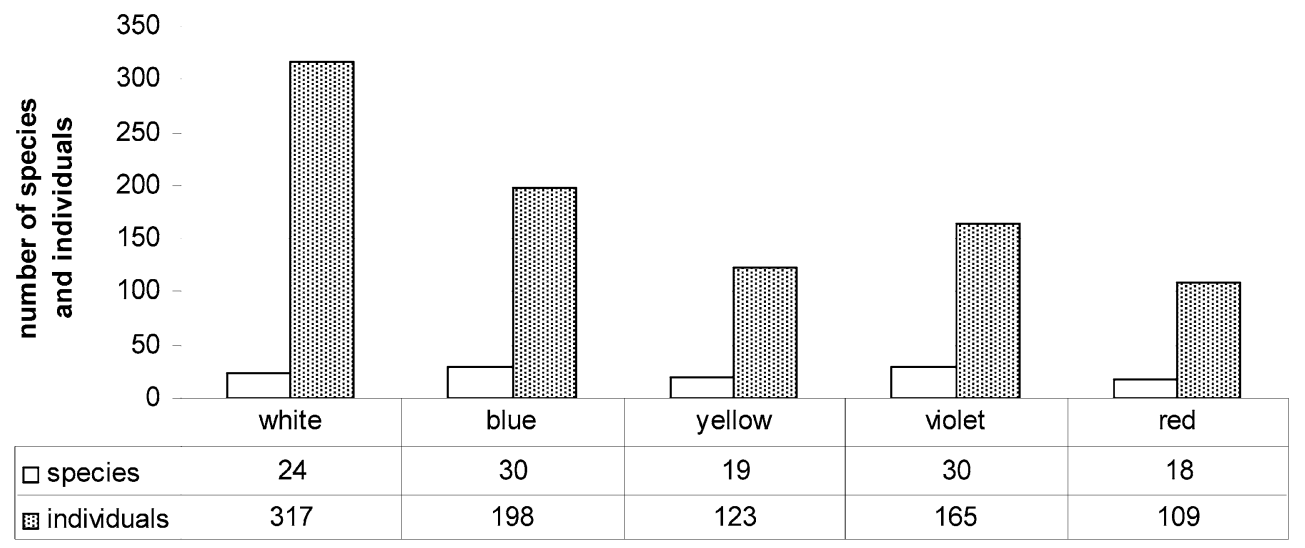

Fig. 2. Number of species and individuals captured to particular colour during the season 2001-2003. 


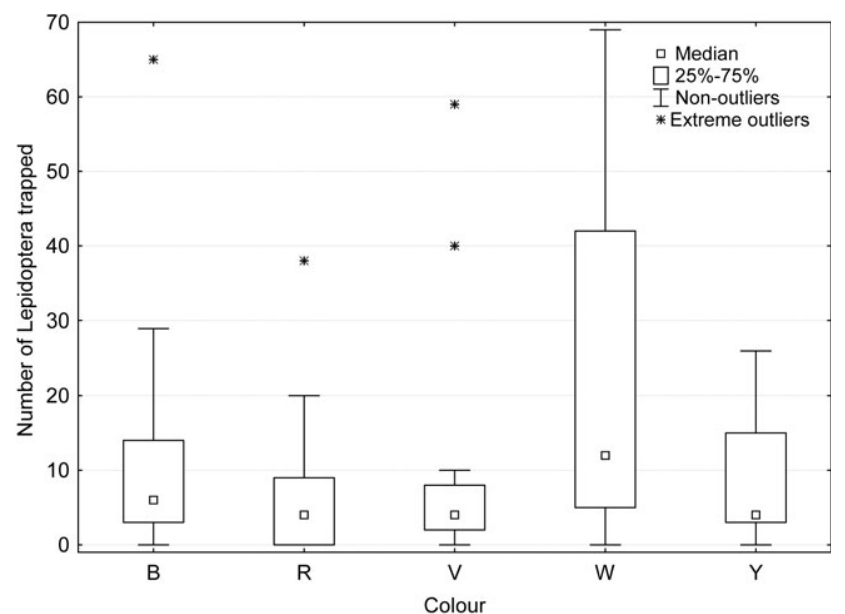

Fig. 3. Number of Lepidoptera per various coloured traps. Square - median; box - percentiles $(25 \%, 75 \%)$; whisker - nonoutlier min, non-outlier max; ${ }^{*}-$ extreme outliers. Abbreviations for colours: B - blue, $\mathrm{R}$ - red, V - violet, $\mathrm{W}$ - white, $\mathrm{Y}$ yellow.

variance in total species and clearly separates white coloured traps from the rest. The second axis explains about $11 \%$ of the variance. White coloured traps thus caught most of the butterfly species. Pieris rapae (total caught 113 of which 103 were caught by white traps) exhibited a clear preference for white flowers, as did Pieris napi (total caught 18 of which 15 were caught by white traps), Hamaeris lucina (total caught 4 of which all were caught by white traps) and Pieris brassicae (total caught 4 of which 3 were caught by white traps). In terms of the attractiveness of different colours for butterflies, blue and violet are interesting because almost similar numbers of some species were caught by both blue and violet pan

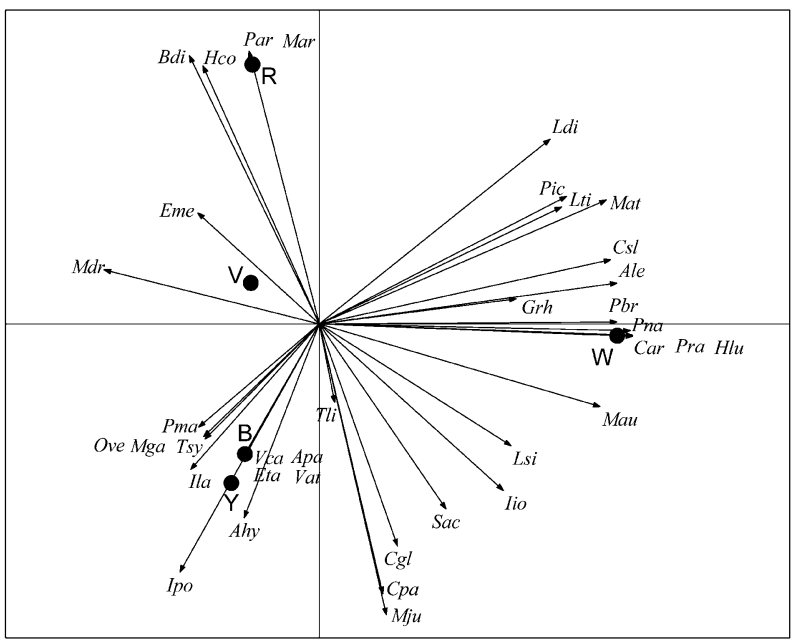

Fig. 4. Ordination diagram based on principal component analysis of Lepidoptera species data from May 2001 to September 2003. The two axes explain $93 \%$ of data variance (eigenvalues of axis: $0.82,0.11$ ). The colour of traps is represented by full circle. Abbreviations for colours: $\mathrm{W}-$ white, $\mathrm{Y}-$ yellow, B - blue, V - violet, $\mathrm{R}$ - red. Infrequent species (abundance equal to 1) were excluded from ordination analysis. For species abbreviations see Table 1 .

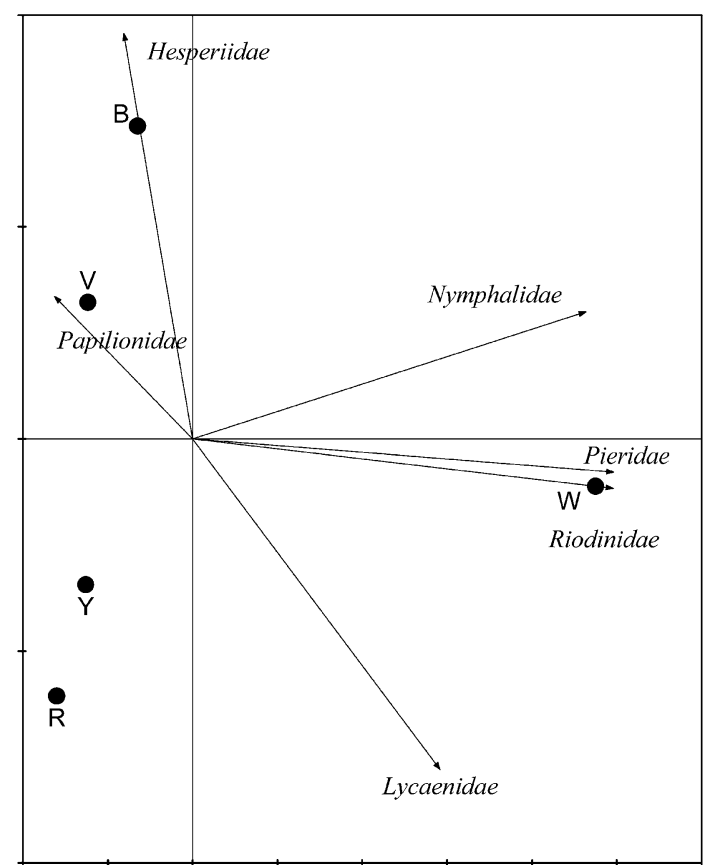

Fig. 5. Ordination diagram based on principal component analysis of Lepidoptera family data from May 2001 to September 2003. The two axes explain $92 \%$ of data variance (eigenvalues of axis: $0.75,0.17)$. The colour of traps is represented by full circle. Abbreviations for colours: W - white, Y yellow, B - blue, $\mathrm{V}$ - violet, $\mathrm{R}$ - red.

traps and some species were not caught by traps of any other colour besides blue and violet. Examples include Pyrgus malvae (blue - 7, violet - 9, of the 19 caught) and Ochlodes venatus (blue - 15, violet -8 , of the 23 caught). Yellow traps were penultimate regarding colour attraction with only one species, Aphantopus hyperantus, markedly attracted to this colour (yellow - 18, of the 23 caught).

Although red coloured traps caught the fewest butterflies, three species showed a clear preference for this colour, Plebeius argus and Maculinea arion and Boloria dia, of which 30 of the total of 76 individuals were caught by red coloured traps.

Principal component analysis shows that for most families there is a positive attraction to a specific colour (Fig. 5). Spacial interrelations in the attractiveness of particular coloured traps are mostly similar to those in Fig. 4. The directions of arrows for the different families reflect those of the species belonging to those families in that they indicate the same coloured traps. Pieridae and Riodinidae (though the latter is only represented by a single species, Hamearis lucina) displayed a strong preference for white. A clear preference for a particular colour was recorded for the family Hesperidae. Over the course of this study 100 individuals belonging to this family were captured of which 43 were caught by blue coloured traps. The remaining families did not show a clear preference for any particular colour. Individuals of the family Papilionidae were attracted to two colours: blue and yellow, and Nymphalidae probably mainly feed on nectar from white and blue coloured flowers and Lycaenidae on that from white, yellow and red flowers. 

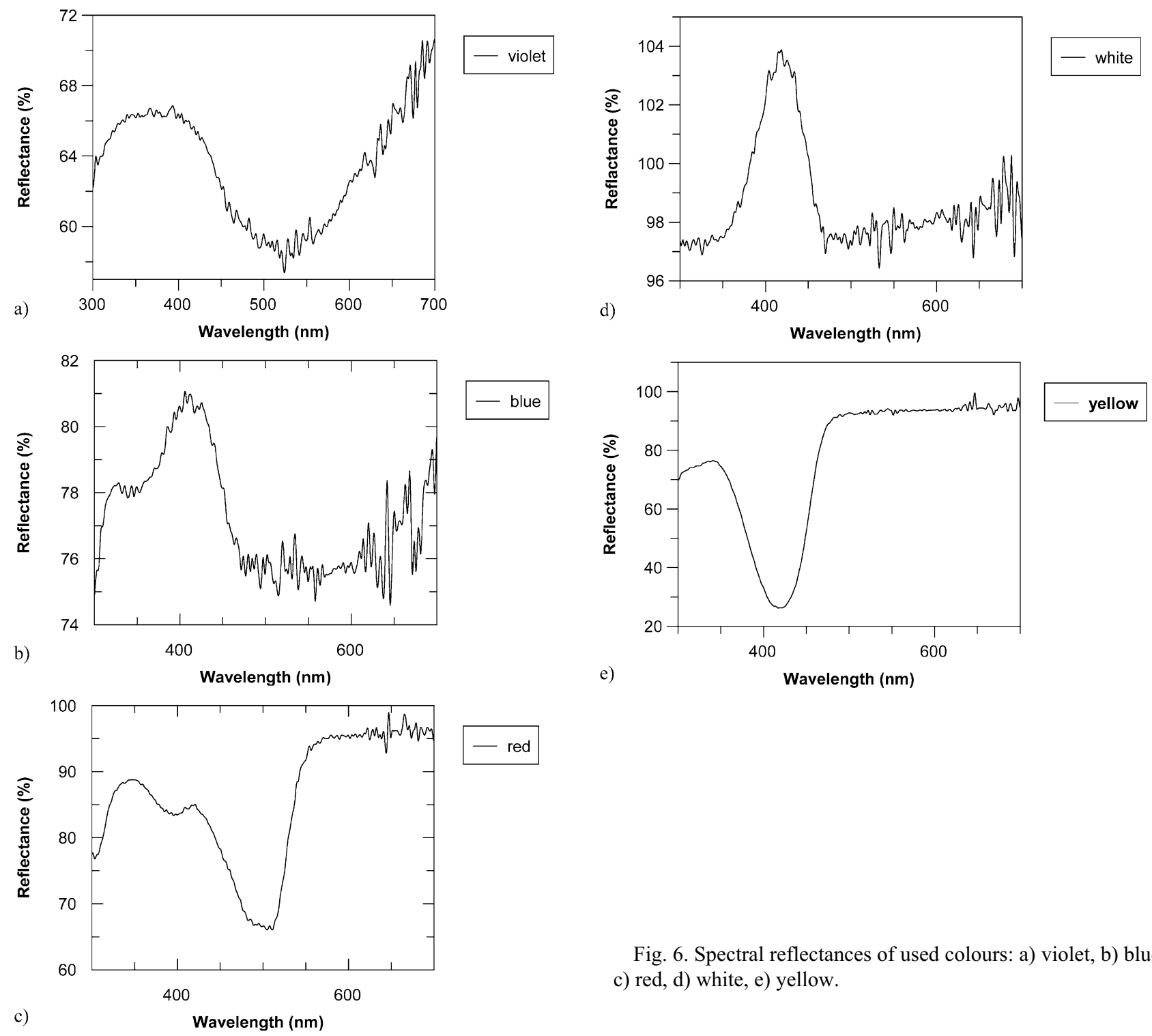

Fig. 6. Spectral reflectances of used colours: a) violet, b) blue, c) red, d) white, e) yellow.

The most common flower colours in the study area were yellow, followed by white, violet and blue and the least common was red. The Spearman's rank correlation coefficient indicates there is no significant correlation between numbers caught and the incidence of flowers of different colours $(r<0.2, P>0.05, \mathrm{df}=167)$.

The results of the spectral measurements of the colours used showed that they were not monochromatic. Generally, in all colours used there was a certain peak in the UV part of the spectrum. This might indicate that butterflies are attracted most by the short-wavelength reflectance of colours, mainly to the white colour which absorbs UV and appearing to be strongly chromatic (namely blue) (Fig. 6)

\section{DISCUSSION}

When we consider colour preference at the species level, 30 of the 53 species were caught by blue and violet, 24 by white and only 18 by red traps. The numbers of species caught by yellow traps are also interesting. Beneš et al. (2000) used yellow-coloured pan traps to sample Lepidoptera. In our study, yellow traps surprisingly were

the next-to-last in catching only 19 of the 53 species. The yellow traps, however, caught the highest numbers of Hymenoptera and Diptera.

The spectral reflectance measurements indicate that butterflies may when searching for a food source respond to the short-wavelength light reflected from flower petals. It is partially confirmed by the numbers of individuals caught by the traps sprayed with colours that reflect light over the entire short wavelength of the spectrum (white 330 , blue -185 , violet -165 , yellow -123 , whereas in red traps - 109).

Ilse (1928) demonstrated that butterflies have inborn preferences for certain colours and that these preferences differ among butterfly families. Our results support this observation as follows: Pieridae and Riodinidae are attracted by white, Hesperidae by blue and Papilionidae by blue and yellow. The remaining families (Lycaenidae and Nymphalidae) do not display a specific colour preference. An interesting discovery revealed by the PCA is that Pieridae and Riodinidae displayed similar values of maximum spectral sensitivity to the same colours as previously reported by Briscoe \& Chittka (2001). 
As shown by Frentiu \& Briscoe (2008), the absorbance spectra of butterflies vary from $340-600 \mathrm{~nm}$. White was the most frequently visited colour, probably because it is best perceived colour by butterflies. This reflectance range is recorded for several wavelengths, but since it absorbs UV, it appears strongly chromatic (namely blue). The absence of red receptor cells in the eyes of some species may account for the red traps catching the fewest butterlies. Most day-active and nocturnal Lepidoptera have a colour vision system based on three or four types of colour receptor cells, which cover the spectral region from UV to red, however having a red receptor does not seem to be a requirement for day-time activity (Briscoe \& Chittka, 2001). The day-active flower-feeding sphingid moth Macroglossum stellatarum, for instance, lacks red receptors, while they are present in the nocturnal noctuid moth Spodoptera exempta. The red receptors appear to be lost or ineffective in members of the butterfly family Nymphalidae. According to the hypothesis that the environment molds photoreceptor spectral sensitivity, such a loss has perhaps occurred repeatedly several times in butterfly phylogeny.

Chittka et al. (1994) report the most frequent and less frequent types of floral spectral reflection functions. The colour reflectances of flower petals have the same character as our measurements. Our spectral measurement showed that spectral reflection functions were not randomly distributed over the spectrum; they had a sharp peak at different wavelengths. White, blue and violet colours were the most attractive for the butterflies. These colours had significant peaks in the blue part of the spectrum. The presence of UV and blue receptors in butterflies could have therefore played a significant role in their choice of colours.

Foraging experience may enable butterflies to modify their colour preference. However, preferential behaviour of flower visitors towards floral colours may develop for different reasons. Inborn colour preferences represent phylogenetic adaptations of species, which function prior to an individual gaining experience from visiting flowers. They respond to foraging signals, independently of the actual reward. Individuals can temporarily acquire a colour preference, but this depends on the learning abilities of these animals and on the rewards provided by different food sources (Lunau \& Maier, 1995).

Although the finding, recognition, acceptance and rejection of a host plant, initiation and maintenance of feeding and selection of an oviposition site are very different actions, they have one thing in common (Szentesi, 2002). Each represents an event for which inputs affect the behaviour. This is important at this level of resolution, although it is assumed that physiological feedback, e.g., experience, modifies behaviour. For this reason, we also thought it was likely that the colour of the flowers of the plants occurring at a given locality could also affect the colour preferences. In Central Europe, the most commonly occurring flowers are white, followed by yellow, violet, red and finally blue flowers (Sláviková, 1996). White flowers are more abundant in high mountains
(39\%) than lowlands (23\%), red flowers are equally abundant at any altitude and blue flowers prevail in the lowlands and yellow flowers in alpine areas high in mountainous regions (Sláviková, 1996). The most common flower colours at our study site were yellow, followed by white, violet, blue and red. There was no correlation between the abundance of flowers of different colours and their attractiveness for the butterflies, although it should be born in mind that categorisation of flower colours by human observers is of a limited value when studying animals with a different colour vision. In species with an additional red receptor, this receptor is involved in creating a preference for colours that appear green to a human observer (Kelber, 1999, 2001).

Although we examined the preference of butterflies for food sources of a particular colour, their preferences may be also determined by the flowers mimicking or being similar to the wing-colour of the opposite sex. In butterflies wing colour is a more striking morphological character than in most other animals. Because wing colour in butterflies is very prominent and varies greatly, it is thought to play a role in, e.g. aposematism, mimicry, species recognition and in the distinction between sexes. The wing surfaces of many species, including Pierids, Nymphalids and Lycaenids have specific pattern that only appear in UV light (Silberglied, 1979; Meyer-Rochow, 1991).

\section{CONCLUSION}

There are few studies on the colour preference of a broad-spectrum of day-active Lepidoptera inhabiting Central Europe. Colour is seen, used and prioritized by butterflies for different reasons, and clearly influences the behaviour of the species and families of Lepidoptera. The most likely explanation for colour prioritizing is an inborn preference for a particular short-wavelength of light. The results presented indicate that the presence of a UV photoreceptor that perceives UV-reflectance and absence of a red photoreceptor may greatly influence the attractiveness of certain coloured flowers for butterflies.

ACKNOWLEDGEMENTS. We thank M. Konvička for valuable suggestions that improved this article, M. Kožurková for her help in measuring the wavelengths and P. Pidaná for her help in collecting material. This study was supported by grants from the Slovak Scientific Grant Agency VEGA no. 1/0434/03, $1 / 0477 / 10,2 / 0042 / 10$ and an Internal Research Grant from the Faculty of Science, UPJŠ no. I-10-001-00-F-VVGS.

\section{REFERENCES}

Arikawa K., Inokuma K. \& Eguchi E. 1987: Pentachromatic visual system in a butterfly. Naturwissenschaften $\mathbf{7 4}$ : 297-298.

BÄschli G. \& Blasco-Yumeta J. 1995: Drosophilidae (Diptera) species of Juniperus thurifera L. forest of Los Monegros region (Spain). Zapateri Rvta Aragon. Entomol. 5: 51-62.

Beneš J., KuRAs T. \& KonviČKa M. 2000: Assemblages of mountainous day-active Lepidoptera in the Hrubý Jeseník Mts, Czech republic. Biologia 55: 159-167.

Briscoe L. \& ChitTKA L. 2001: The evolution color vision in insect. Annu. Rev. Entomol. 46: 471-510. 
Frentiu F.D. \& Briscoe A.D. 2008: A butterfly eye's view of birds. Bio Essays 30: 1151-1162.

Giurfa M., NúÑez J., Chittka L. \& Menzel R. 1995: Colour preferences of flower-naive honeybees. J. Comp. Physiol. (A) 177: $247-259$.

GoldSMith T.H. 1990: Optimization, constraint and history in the evolution of eyes. Q. Rev. Biol. 65: 281-322.

Goulson D. \& CORY J.S. 1993: Flower constancy and learning in foraging preferences of the green-veined white butterfly Pieris napi. Ecol. Entomol. 18: 315-320.

Grissel E.E. \& Schauff M.E. 1997b: A Handbook of the Families of Nearctic Chalcidoidae (Hymenoptera). Entomological Society of Washington, Washington, D.C., 87 pp.

ChiтtKa L. 1997: Bee color vision is optimal for coding flower colours, but flower colours are not optimal for being coded why? Israel J. Plant. Sci. 45: 115-127.

ChittKa L. \& Menzel R. 1992: The evolutionary adaptation of flower colours and the insect pollinators' colour vision. $J$. Comp. Physiol. (A) 171: 171-181.

ChitTKA L. \& RaINE N.E. 2006: Recognition of flowers by pollinators. Curr. Opin. Plant Biol. 9: 428-435.

Chittka L., Shmida A., Troje N. \& Menzel R. 1994: Ultraviolet as a component of flower reflections, and the colour perception of Hymenoptera. Vision Res. 34: 1489-1508.

ILSE D. 1928: Über den farbensinn der Tagfalter. J. Comp. Physiol. 8: 658-692.

Kelber A. 1999: Ovipositing butterflies use a red receptor to see green. J. Exp. Biol. 202: 2619-2630.

KeLBER A. 2001: Receptor based models for spontaneous colour choices in flies and butterflies. Entomol. Exp. Appl. 99: 231-244.

Kinoshita M., Shimada N. \& Arikawa K. 1999: Colour vision of the foraging swallowtail butterfly Papilio xuthus. J. Exp. Biol. 202: 95-102.

Kocourek F., LÁsKa P. \& JarošíK V. 2002: Thermal requirements for flight of six species of flea beetle of the genus Phyllotreta (Coleoptera: Chrysomelidae). Plant. Protect. Sci. 38: $73-77$.

LAŠTƯVKA Z. 1998: Checklist of Lepidoptera of the Czech and Slovak Republics (Insecta, Lepidoptera). Konvoj, Brno, 118 pp.

LunAu K. \& MAIER E.J. 1995: Innate colour preferences of flower visitors. J. Comp. Physiol. (A) 177: 1-19.

MeYer-Rochow V.B. 1991: Differences in ultraviolet wing patterns in the New Zealand lycaenid butterflies Lycaena salustius, L. rauparaha and L. feredayi as a likely isolating mechanism. J. Roy. Soc. N.Z. 21: 169-177.
MoEricKe V. 1951: Eine Farballe zur Kontrolle des Fluges von Blattlausen insbesondere der Pfirschblattlaus Myzodes persicae (Sulz.). Nachr.-Bl. Dtsch. Pfl.-Schutzdienst 3: 23-24.

Prajakta B., Balasubramanian S. \& Milind W. 2009. The cooptimization of floral display and nectar reward. J. Biosciences 34: 963-967.

ROHÁČEK J., BARTÁK M. \& KUBÍK Š. 1998: Diptera Acalyptrata of the Hraniční (Luzenská) slat' peat bog in the Šumava Mts. (Czech Republic). Časopis Slezského Muzea, Opava (A) 47: $1-12$.

SASAKI H. 2001: Comparison of capturing tabanid flies (Diptera: Tabanidae) by five different color traps in the fields. Appl. Entomol. Zool. 36: 515-519.

Silberglied R.E. 1979: Communication in the ultraviolet. Annu. Rev. Ecol. Syst. 10: 373-398.

SLÁviKová Z. 1996: Barvy květů a způsoby opylování. [Flower colours and ways of pollination.] Živa 3: 106-108 [in Czech].

Spaethe J., Tautz J. \& ChitTKa L. 2001: Visual constraints in foraging bumblebees: Flower size and color affect search time and flight behavior. Proc. Nat. Acad. Sci. 98: 3898-3903.

Stange G. 1997. Effects of the changes in atmospheric carbon dioxide on the location of hosts by the moth Cactoblastis cactorum. Oecologia 110: 539-545.

StatSoft Inc. 2009: STATISTICA (data analysis software system), version 9.0. www.statsoft.com.

Straka V., Panigaj L. \& Gábriková D. 2010: True flies (Diptera) of meadows: there is a relationship to the color of flowers? Naturae Tutela 14: 183-194 [in Slovak].

SzÉNTESI Á. 2002: Insect-plant relationship - chance and necessity. Acta Zool. Hung. 48: 55-71.

ter Braak C.J.F. \& S Smilauer P. 2002: CaNOCO Reference Manual and CanoDraw for Windows User's guide: Software for Canonical Community Ordination (version 4.5). Microcomputer Power, New York, 500 pp.

WeIss M.R. 1995a: Associative colour learning in a nymphalid butterfly. Ecol. Entomol. 20: 298-301.

WeIss M.R. 1995b: Floral colour change: A wide spread functional convergence. Am. J. Bot. 82: 167-185.

Yaku A., Walter G.H. \& Najar-Rodriguez A.J. 2007: Thrips see red - flower colour and the host relationships of a polyphagous anthophilic thrips. Ecol. Entomol. 32: 527-535.

zur Strassen R., Lucasia S. \& Blasco-Zumeta J. 1997: Thrips of Juniperus thurifera L. forest of Los Monegros region (Spain). Zapateri Rvta Aragon. Entomol. 7: 251-268.

Received May 13, 2011; revised and accepted February 15, 2012 